\title{
Perceive Value as a Moderator on the Relationship between Service Quality Features and Customer Satisfaction
}

\author{
Azman Ismail \& Norashyikin Alli \\ Faculty of Cognitive Sciences \& Human Development \\ Universiti Malaysia Sarawak \\ Kuching, Sarawak, Malaysia \\ Tel: 60-82-581-521_E-mail: iazman@fcs.unimas.my \\ Muhammad Madi Abdullah \\ College of Business Management and Accounting \\ Universiti Tenaga Nasional \\ Bandar Muadzam Shah 26700, Pahang, Malaysia \\ Tel: 60-9-455-200 E-mail: madi@uniten.edu.my \\ Associate Professor Balakrishnan Parasuraman (Corresponding author) \\ Industrial Relations Program \\ School of Social Sciences \\ Universiti Malaysia Sabah \\ PO Box 22144, Kota Kinabalu 88781, Sabah, Malaysia \\ Tel: 60-12-839-6343 E-mail:bp05@hotmail.com
}

\begin{abstract}
Quality management (QM) literature highlights that service quality is a critical determinant of organizational competitiveness. The ability of an organization implements service quality program will positively motivate customers' perceive value; this may lead to increased their satisfaction. The nature of this relationship is less emphasized in service quality service models. In this study, a survey research method was used to gather 102 usable questionnaires from academic staffs who have studied in one Malaysian public institution of higher learning in East Malaysia (HIGHINSTITUTION). The outcomes of hierarchical regression analysis showed three important findings: firstly, interaction between perceive value and responsiveness insignificantly correlated with customer satisfaction. Secondly, interaction between perceive value and assurance insignificantly correlated with customer satisfaction and thirdly, interaction between perceive value and emphathy significantly correlated with customer satisfaction. This result demonstrates that perceive value has increased the effect of emphathy customer satisfaction, but perceive value has not increased the effect of responsiveness and assurance on customer satisfaction. Further, this study confirms that perceive value does act as a partial moderating variable in the service quality models of the organizational sample. In addition, implications and limitations of this study, as well as directions for future research are discussed.
\end{abstract}

Keywords: Service quality, Perceive value and customer satisfaction

\section{Introduction}

Service quality and customer satisfaction are inarguably the two core concepts that are at the crux of the marketing theory and practice (Spreng and Mackoy, 1996). In today's world of intense competition, the key to sustainable competitive advantage lies in delivering high quality services that will in turn result in satisfied customers (Shemwell et al., 1998). Therefore, there is not even an iota of doubt concerning the importance of service quality as the ultimate goal 
of service providers throughout the world (Sureshchandar et al., 2002). In an era of global competition; many organizations have now shifted the paradigm of service quality to customer's perspective (Parasuraman et al., 1985). Rely on this paradigm; a customer will judge the quality of service if its service meets his/her expectations (Grönroos, 1984; Parasuraman et al., 1985, 1988). Many scholars think that employee satisfaction with the service features may increase retention and loyalty (Alexandris et al., 2002), thus lead to increased organizational competitiveness (Shemwell et al., 1998).

\section{Service quality}

Service quality has been defined as a form of attitude - a long-run overall evaluation (Zeithaml, 1988; Parasuraman et al., 1988). Perceived service quality portrays a general; overall appraisal of service, i.e. a global value judgement on the superiority of the overall services and it could occur at multiple levels in an organization (Sureshchandar et al., 2002). Many scholars such as Parasuraman et al. (1988), Juwaheer and Ross (2003) and Walker et al. (2006) highlight that responsiveness; assurance and empathy are the most important service quality features. Responsiveness is often defined as the willingness of service provider to provide service quickly and accurately (Juwaheer \& Ross, 2003). Assurance refers to credibility, competence and security in delivering services (Juwaheer \& Ross, 2003). Empathy is related to caring, attention and understanding the customer needs when providing services (Juwaheer \& Ross, 2003).

Extant research in this area shows that properly implementing such service quality features may increase customer satisfaction (Gronroos, 1984; Parasuraman et al., 1988; Walker et al., 2006). In a quality management context, customer satisfaction is defined as a result of comparison between what one customer expects about services provided by a service provider and what one customer receives actual services by a service provider (Caruana et al., 2000; Parasuraman et al., 1988). If services provided by an organization meet a customer's needs, this may lead to higher customer satisfaction (Foster, 2004; Parasuraman et al., 1988; Walker et al., 2006).

Surprisingly, a thorough investigation of such relationships reveals that effect of service quality features on customer satisfaction is not consistent if perceive value is present in organizations (Caruana et al., 2000; Varki \& Colgate, 2001). Perceive value is considered as customer recognition and appreciation the utility of a product that is given by a service provider which may fullfil his/her expectation (Foster, 2004; Heininen, 2004; Walker et al., 2006). In a service management context, the ability of an organization to use responsiveness, assurance and empathy in delivering services will increase customers' perceptions of value; this may lead to higher customer satisfaction (Sureshchandar, 2000; Sureshchandar et al., 2002). Even though many studies have been done, little is known about the moderating effect of perceive value in service quality models. Hence, it motivates the researchers to measure the moderating effect of perceive value in the relationship between service quality features and customer satisfaction that occurs in one Malaysian public university in East Malaysia. For confidential reasons, name of the organization is kept anonymous.

\section{Literature review}

Several studies about soft quality program in Western organizational settings show that service quality may indirectly and directly affect customer satisfaction. In terms of direct relationship perspective, Bitner (1990) examined the quality service based on a sample of 145 tourists and found that service quality had been an important antecedent of customer satisfaction. In addition, Caruana et al. (2000) conducted a research on 80 personal interviews with customers of the audit firm and found that service quality positively correlated with perceived value. Extant research in this area reveals that relationship between service quality and customer satisfaction is strongly moderated by perceive value. For example, Eggert and Ulaga (2002) conducted a study about customer satisfaction based on 301 employees in US organizations. This study found that properly implementing service quality features (i.e., assurance, empathy, reliability, responsiveness and tangibles) have increased individuals' perceive value about the quality features. As a result, it might lead to an increased customer satisfaction.

The service qualiy research literature is consistent with the notion of perceive quality models. For example, Parasuraman et al. (1985) conceptual service quality model highlights that matching between service quality standards and customers' standards may decrease service performance gap and increase customers' perceive value about the quality systems. Consequently, it may lead to higher customer satisfaction.

The literature has been used to develop the conceptual framework for this study as shown in Figure 1.

\section{Insert Figure 1 here}

Based on the framework, this study hypothesizes that:

H1: There is a positive relationship between service quality features and customer satisfaction

H2: Perceive value moderates the relationship between service quality features and customer satisfaction 


\section{Methodology}

\subsection{Research Design}

This study used a cross-sectional research design which allowed the researchers to integrate service quality literature, in-depth interviews, pilot study and the actual survey as a main procedure to gather accurate and less bias data (Davis, 1996; Cresswell, 1998; Sekaran, 2000). This study was conducted in one public institution of higher learning in East Malaysia (HIGHINSTITUTION). In this institution, one center for teaching and learning has been established to develop and management sophisticated teaching and learning facilities in central teaching buildings. This center uses teaching and learning quality standards set up by the Ministry of Higher Education, Malaysia to set up and manage lecture theatres and lecture halls in the teaching buildings.

In order to understand the nature of quality service, in-depth interviews were first conducted involving four experienced officers, that is one assistant registrar, one information system manager, one assistant administrative officer, and one supporting staff who have worked in the center. They are selected based on purposive sampling where the employees have good knowledge and experiences in designing and administering quality service program. Information gathered from such employees helped the researchers to understand the nature of quality service policies and procedures, employees' perceptions of value about service quality and customer satisfaction characteristics, as well as the relationship between such variables in the studied organizations. After refining, categorizing and comparing the information with relevant theoretical and empirical evidence, this was used as a guideline to develop the content of survey questionnaires for a pilot study. Next, a pilot study was conducted by discussing survey questionnaires with five experienced academic staff that have backgrounds in social sciences, humanities, sciences and technology. This information was used to verify the content and format of a survey questionnaire for an actual research.

\subsection{Measures}

Back translation technique was used to translate the content of questionnaires in Malay and English in order to increase the validity and reliability of the instrument (Wright, 1996). The survey questionnaire was developed based on the modification of SERVQUAL instrument (Parasuraman et al., 1985). This questionnaire consists of three major sections: firstly, responsiveness was measured using 4 items. The items used to measure this variable were (1) repair teaching and learning facilities, (2) assist academic staff in operating teaching and learning facilities, (3) booking system for lecture halls and/or lecture theatres and (4) ready to assist academic staff if needed. Secondly, assurance was measured using 3 items. The items used to measure this variable were (1) confidence in the service provider, (2) comfortable in dealing with the service provider and (3) efficiency in providing services. Thirdly, empathy was measured using 3 items. The items used to measure this variable were (1) understandable about academic staffs' needs; (2) put a priority in monitoring central teaching buildings and (3) ability of fullfiling the academic staffs' requests.

Fourthly, perceive value had 3 items that were modified from service quality related perceive value (Monroe, 1990; Caruana et al., 2000; Foster, 2004). The items used to measure this variable were (1) teaching and learning facilities are useful for teaching and learning, (2) teaching and learning facilities help to improve teachings and teaching and (3) teaching and learning spaces are comfortable for teaching activities. Fifthly, customer satisfaction had 4 items that were modified from service quality related customer satisfaction (Bitner, 1990; Eggert and Ulaga, 2002; Walker et al., 2006). The items used to measure this variable were satisfaction or dissatisfaction with (1) the service provider's attitude and behavior, (2) the ability of service provider treats academic staff, (3) the ability of service provider communicates with academic staff and (4) the willingness of service provider to maintain the teaching and learning conditions of central teaching buildings. All these items were measured using a 7-item scale ranging from "very strongly disagree" (1) to "very strongly agree" (7). Demographic variables were used as a controlling variable because this study focused on employee attitudes.

\subsection{Sample}

The unit of analysis for this study is academic staffs who have worked in the HIGHINSTITUTION. In the first step of data collection procedure, the researchers met the university's HR department to find out about the rules for distributing survey questionnaires to academic staff. Considering the organizational rule, a convenient sampling technique was used to distribute 120 questionnaires to academic staff in all faculties at the main campus of the university. Of that total, 102 usable questionnaires were returned to the researchers, yielding 84 percent response rate. The survey questionnaires were answered by participants based on their consents and a voluntarily basis.

\subsection{Data analysis}

A statistical package for social science (SPSS) version 15.0 was used to analyze the questionnaire data. Firstly, exploratory factor analysis was used to assess the validity and reliability of measurement scales (Hair et al, 1998). Secondly, Pearson correlation analysis and descriptive statistics were conducted to determine the collinearity problem and the usefulness of the data set. Finally, a hierarchical regression analysis as recommended by Cohen \& Cohen (1983) was used to measure the moderating effect of perceive value in the hypothesized model. Moderating effect is an 
interaction that shows the degree of relationship between the independent variables and dependent variables will change if other variables exist in the relationship (Cohen \& Cohen, 1983; Jaccard et al., 1990). Results of an interaction are evident when the relationship between interacting terms and the dependent variable is significant. The fact that the significant main effects of predictor variables and moderator variables simultaneously exist in analysis it does not affect the moderator hypothesis and is significant to interpret the interaction term (Baron \& Kenny, 1986).

\section{Findings}

\subsection{Sample profile}

In relation to sample profile, Table 1 shows that the majority respondent characteristics were females $(58.8 \%)$, ages between 31 to 35 years old (54.9\%), masters degree (80.4\%), serve between 4 to 7 years $(49.0 \%)$, and lecturers who had backgrounds in social sciences and humanities $(58.0 \%)$.

\section{Insert Table 1 here}

\subsection{Validity and reliability analyses for measurement scales}

The validity and reliability analyses were conducted based on the procedures established by Hair et al. (1998), and Nunally and Berstein (1994). A principal component factor analysis with oblique rotation using direct oblimin was used to determine the possible dimensions of the constructs. Further, The Kaiser-Mayer-Olkin Test (KMO) which is a measure of sampling adequacy was conducted for each variable and the results indicated that it was acceptable. The original survey questionnaires have 48 items which are related to five variables: responsibility ( 7 items), assurance ( 7 items), empathy (7 items), perceive value ( 7 items) and customer satisfaction (10 items). The factor analysis was conducted to condense the 31 items to 17 items.

Table 2 shows the results of validity and reliability analyses where (1) all research variables exceeded the minimum standard of Kaiser-Meyer-Olkin's value of 0.6, were significant in Bartlett's test of sphericity, (2) all research variables had eigenvalues larger than 1, and (3) the items for each variable exceeded factor loadings of 0.40 (Hair et al., 1998), and (4) all variables exceeded the acceptable standard of reliability analysis of 0.70 (Nunally \& Bernstein, 1994). These statistical results support the notion of perceive value theories (Parasuraman et al., 1985; Kano, 1984), and empirical studies (Eggert \& Ulaga, 2002; Varki \& Colgate, 2001), signifying the goodness of data for this study.

\section{Insert Table 2 here}

Table 3 shows that the mean values for each variable are between 5.01 and 5.43, indicating the level of responsiveness, assurance and empathy, perceive value and customer satisfaction are ranging from high (4) to highest level (7). The Pearson correlation coefficients between the independent variables (i.e., responsiveness, assurance and empathy) and moderating variable (i.e., perceive value) and between dependent variable (i.e., customer satisfaction) were less than 0.90 , indicating the data are not affected by serious colinearity problem. These correlations also provide further evidence of validity and reliability for measurement scales used in this research (Hair et al., 1998).

\section{Insert Table 3 here}

\section{Insert Table 4 here}

The table shows the outcomes of testing moderating hypotheses in Model 3. Firstly, interacting variable (responsiveness x perceive value) insignificantly correlated with customer satisfaction $(\beta=-0.22, \mathrm{p}>0.05)$, therefore H1 was rejected. This result demonstrates that the inclusion of perceive value had not increased the effect of responsiveness on customer satisfaction. This indicates that perceive value does not act as a moderating variable in such relationships.

Secondly, interacting variable (assurance $\mathrm{x}$ perceive value) is also insignificantly correlated with customer satisfaction $(\beta=-1.83, p>0.05)$, therefore $\mathrm{H} 2$ was rejected. This result demonstrates that the inclusion of perceive value had not increased the effect of assurance on customer satisfaction. This indicates that perceive value does not act as a moderating variable in such relationships.

Thirdly, interacting variable (empathy $x$ perceive value) significantly correlated with customer satisfaction $(\beta=1.72$, $\mathrm{p}<0.05$ ), therefore $\mathrm{H} 3$ was accepted. This result demonstrates that the inclusion of perceive value had increased the effect of empathy on customer satisfaction. This indicates that perceive value does act as a moderating variable in such relationships.

\section{Discussion, implications, limitations and directions for future research}

The finding for this research shows that perceive value does act only as a partial moderator in the overall relationship between service quality features and customer satisfaction. In the context of HIGHINSTITUTION, the service provider (center for teaching and learning) is given a major responsibility to plan, maintain, and monitor sophisticated teaching and learning facilities (i.e., lightings, air-conditioners, computers, multimedia and physical equipments) in the central teaching buildings based on the rules set up by the university leadership. These practices have increased the quality of delivering teaching and learning services (i.e., responsiveness, assurance and empathy), this may increase academic 
staffs' perceive value about the service features. Although such perceptions of value are high, majority academic staffs feel that empathy in delivering of teaching and learning services can only increase their satisfaction whreas perceptions of value about the use of responsiveness and assurance in delivering of teaching and learning services cannot increase academic staffs' satisfaction.

Based on the information gathered from the in-deph interview, perceive value does not able to moderate the relationship between responsiveness, assurance and customer satisfaction and this may be caused by several external factors. Firstly, the teaching and learning facilities in the central teaching buildings are intensively used from morning to night within learning semesters for the purposes of teachings, seminars, short courses and workshops. If these teaching and learning facilities are not properly used, this may not be repaired or replaced with other equipments within short time. The duration of repairing and/or replacing with other equipments will take long time; this may increase academic staffs' complaints and criticisms to the service provider.

Secondly, as a new campus, the teaching and learning facilities in the central teaching buildings are properly installed and managed by the service provider. For example, the service provider is given a major responsibility to provide teaching and learning aids for particular purposes such as teaching, seminar, short courses and workshops. Although the service provider may provide teaching and learning equipments, it does not have sufficient equipments that meet academic staffs' expectations. Besides that, the service provider does not have enough staff that may monitor and maintain the requested equipments if many functions are done at several lecture theatres and lecture halls in central teaching buildings. Inability to manage such teaching and learning facilities may decrease comfortable, trust and courtesy of academic staffs when organizing teaching, seminar, short courses and workshops teaching in the central teaching buildings. As a result, it may lead to increased academic staffs' feelings of dissatisfaction and misjudgment about the services.

This study provides significant impacts on three major aspects: theoretical contribution, robustness of research methodology, and practical contribution. In terms of theoretical contribution, this study provides two important findings: firstly, perceive value about the use of empathy in teaching and learning services has increased customer satisfaction. This finding is consistent with studies by Eggert and Ulaga (2002) and Varki \& Colgate (2001). Secondly, perceive value about the use of responsiveness and assurance in delivery teaching and learning services have not increased customer satisfaction. This result is not consistent with studies conducted by Caruana et al. (2000), Eggert and Ulaga (2002) and Monroe (1990). The findings of this study show that majority of academic staff perceive that the ability of service provider to properly use empathy in delivering teaching and learning services will increase their perceptions of value about the services. As a result, it may lead to an increased academic staffs' satisfaction in the organization.

Regarding the robustness of research methodology, the data gathered using service quality literature, the in-depth interviews, pilot study and survey questionnaires have exceeded a minimum standard of validity and reliability analyses, this can lead to the production of accurate and reliable findings. With respect to practical contribution, the findings of this study can be used as a guideline by management to improve the design and administration of service quality program in organizations. Specifically, the design and management of service quality may be improved if managers emphasize on the suggestions: firstly, staff who involve in providing teaching and learning facilities need to be given proper quality management training programs. Through this training program, the staff may increase their understanding about the concept and importance of practising new knowledge, skills and good moral values. As a result, it may lead to improved job quality.

Secondly, staffs who involve in providing teaching and learning facilities need to be given better rewards. For example, staffs who involve improving teaching and learning facilities are from low level positions. By providing monetary incentives for the staff who involve in working overtime will invoke their satisfaction, this may lead to increased motivation to perform job better. Thirdly, recruitment policy needs to be changed from hiring fresh employees to experienced employees. Stafs that involve in providing teaching and learning facilities are usually dealing with professional employees. If an organization hires experienced staff this will decrease mistake and increase efficiency in installing, maintaining and monitoring sophisticated teaching and learning facilities. As a result, it may lead to an improved customer service. Considering such factors in developing and managing teaching and learning services will help academic staff to improve their teaching and learning activities, this may lead to increased students' understanding about up to date knowledge, skills and attitudes that they learn from their lecturers. Thus, it may lead to increase the effectiveness of teaching and learning in universities.

The conclusion drawn from the results of this study should consider the following limitations. Firstly, this study was a cross-sectional research design where the data were taken one time within the duration of this study. This research design did not capture the developmental issues (e.g., intra-individual change and restrictions of making inference to participants) and/or causal connections between variables of interest. Secondly, this study only examines the relationship between latent variables (i.e., responsiveness, assurance, empathy, perceive value and customer satisfaction) and the conclusion drawn from this study does not specify the relationship between specific indicators for the 
independent variable, moderating variable, and dependent variable. Thirdly, the outcomes of multiple regression analysis have focused on the level of performance variation explained by the regression equations and it is also helpful to indicate the amount of dependent variable variation not explained (Tabachnick \& Fidell, 2001). Although a substantial amount of variance in dependent measure explained by the significant predictors is identified, there are still a number of unexplained factors that can be incorporated to identify the causal relationship among variables and their relative explanatory power. Therefore, one should be cautious about generalising the statistical results of this study. Finally, the sample of this study only used academic staff in a single university and they were chosen by using a convenient sampling technique. The nature of this sample may decrease the ability of generalizing the results of this research to other organisational settings.

The conceptual and methodological limitations of this study need to be considered when designing future research. Firstly, this study sets a foundation for research on relationships between service qualities, perceive value and customer satisfaction. It has raised many questions as well as confirming initial propositions. A few research areas can be further explored as a result of this study. Secondly, the organisational and personal characteristics as a potential variable that can influence perceive value about service quality needs to be further explored. Using these organisational (e.g., ownership and type) and personal (e.g., sex, age and position) characteristics may provide meaningful perspectives for understanding of how individual similarities and differences affect service quality policies within an organisation. Thirdly, the cross-sectional research design has a number of shortcomings; therefore other research designs such as longitudinal studies should be used as a procedure for collecting data and describing the patterns of change and the direction and magnitude of causal relationships between variables of interest. Fourthly, the findings of this study rely very much on the sample taken from one organisational sector. To fully understand the effect of service quality on individual attitudes and behaviours via its impact upon perceive value, more organisational sector (e.g., government link companies, business organizations, and non-profit organisations) need to be used in future study. Finally, other personal outcomes of perceive value such as retention and loyalty should be considered in future research because they are given more attention in considerable service quality literature (Alexandris et al., 2000; Parasuraman et al., 1988; Walker et al., 2006). The importance of these issues needs to be further explained in future research.

In sum, the findings of this study confirm that perceive value does act as a partial moderating role in the service quality model of the organization. These results have partially supported and broadened service quality research literature published in most Western countries. Therefore, current research and practice within service quality models needs to consider individuals' perceive value as a critical aspect of service quality. The findings of this study further suggest that perceive value should be seen as a crucial aspect of service quality where perceive value about service quality may strongly induce positive subsequent personal outcomes (e.g., satisfaction, retention and thus loyalty). Thus, it may lead employees to maintain and increase academic excellent in universities.

\section{References}

Alexandris, K, Dimitriadis, N. \& Markata, D. (2002). Can perceptions of service quality predict behavioural intentions? An exploratory study in the hotel sector in Greece. Managing Service Quality, 12(4), $224-231$.

Baron, R.M. \& Kenny, D.A. (1986). This moderator-mediator variable distinction in social psychological research: Conceptual, strategic and statistical considerations. Journal of Personality and Social Psychological, 51, 1173-1182.

Bitner, M.J. (1990). Evaluating service encounters: the effects of physical surroundings and employee response. Journal of Marketing, 2, 69-82.

Caruana, A., Money, A.H. \& Berthon P.R. (2000). Service quality and satisfaction - the moderating role of value. European Journal of Marketing, 34(11/12), 1338-1352.

Cohen, J., \& Cohen, P. (1983). Applied multiple regression/correlation analysis for the behavioural sciences. Hillsdale, NJ: Erlbaum.

Creswell, J. W. (1998). Quality inquiry and research design: choosing among five traditions. London: SAGE Publication.

Davis, D. (1996). Business Research for Decision Making (4 Ed.). Belmot: Duxbury Press.

Eggert, A. \& Ulaga, W. (2002). Customer perceived value: a substitute for satisfaction in business markets? Journal of Business \& Industrial Marketing, 17(2/3), 107-118.

Foster, S. T. (2004). Managing Quality: An Integrative Approach. New Jersey: Prantice Hall.

Fraenkel, J.R., \& Wallen, N.E. (1993). How to design and evaluate research in Education (2 ${ }^{\text {nd }}$ Ed.). McGraw-Hill.

Gonroos, C. (1984). A service quality model and its market implications. European Journal of Marketing, 18(4), 36-44.

Hair, J.F., Anderson, R.E., Tatham, R.L., \& Black, W.C. (1998). Multivariate data analysis. New Jersey: Prentice-Hall International, Inc. 
Heininen, K. (2004). Reconceptualizing customer perceived value: the value of time and place. Managing Service Quality, 14(2/3), 205-215.

Jaccard, J., Turrisi, R., \& Wan, C.K. (1990). Interaction effects in multiple regression. Newsbury Park, California: SAGE Publications, inc.

Juwaheer, T. D. \& Ross, D. L. (2003). A study of guest perceptions in Mauritius. International Journal of Hospitality Management, 15(2), 105-115.

Nunally, J.C. \& Bernstein, I.H. (1994). Psychometric Theory. New York: McGraw-Hill.

Parasuraman, A., Zeithaml, V. A. \& Berry, L. L. (1985). A conceptual model of service quality and its implication for future research. Journal of Marketing, No. 49, 41-50.

Parasuraman, A., Zeithaml, V. A. \& Berry, L. L. (1988). SERVQUAL: a multiple-item scale for measuring consumer perceptions of service quality. Journal of Retailing, 64(1), 12-40.

Sekaran, U. (2000). Research methods for business: A skill building approach. New York: John Wiley \& Sins, Inc.

Shemwell, D.J., Yavas, U. \& Bilgin Z. (1998). Customer-service provider relationships: an empirical test of a model of service quality, satisfaction and relationship oriented outcome. International Journal of Service Industry Management, 9 , 155-168.

Spreng, R.A., \& Mackoy, R.D. (1996). An empirical examination of a model of perceived service quality and satisfaction. Journal of Retailing, 72, 201-214.

Sureshchandar, G.S. (2000). Development of a framework for total quality service - the case of banks in India. Unpublished doctoral dissertation, Indian Institute of Technology Madras.

Sureshchandar, G.S., Rajendran, C. \& Anantharaman, R. N. (2002). The relationship between service quality and customer satisfaction - a factor specific approach. Journal of Services Marketing, 16(4), 363-379.

Tabachnick, B.G., \& Fidell, L.S. (2001). Using multivariate statistics. Sydney: Allyn and Bacon.

Varki, S. \& Colgate, M. (2001). The role of price perceptions in an integrated model of behavioural intentions. Journal of Service Research, 3(3), 232-40.

Walker, R. H., Johnson, L.W. \& Leonard, S. (2006). Re-thinking the conceptualization of customer value and service quality within the service-profit chain. Managing Service Quality, 16(1), 23-36.

Wright, I.L. (1996). Quality International management Research, In Punnett, B.J. \& Shenkar, O. Handbook for International Management Research. Oxford, UK: BlackWell Publishers Inc. 63-81.

Zeithaml, V. A. (1988). Consumer perceptions of price, quality, and value: a means-end model and synthesis of evidence. Journal of Marketing, 52, 2-22

Zeithaml, V. A., \& Bitner, M. J. (2000). Services Marketing: Integrating Customer Focus across the Firm. New York: McGraw-Hill.

Independent Variables

\begin{tabular}{l} 
Service Quality Features \\
- Assurance \\
- Empathy \\
- Responsiveness \\
\hline
\end{tabular}

Dependent Variable

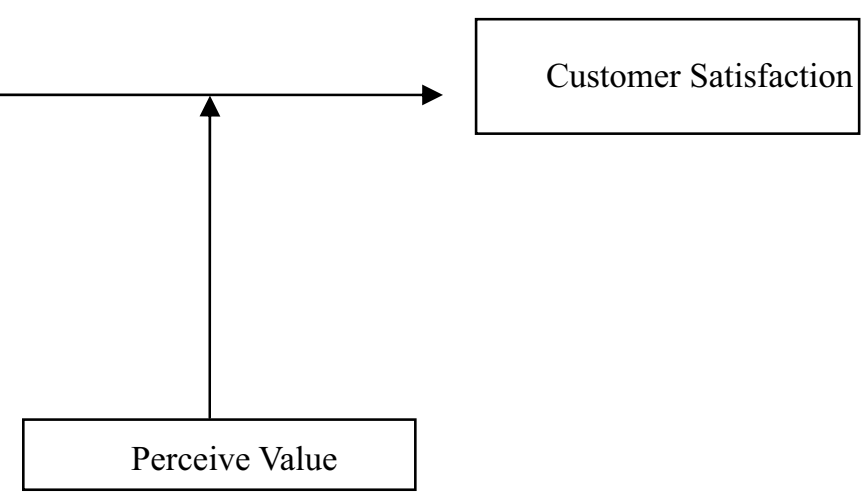

Moderating Variable

Figure 1. Research model of perceive value as a moderator on the relationship between service quality features and customer satisfaction 
Table 1. Profile of Respondents ( $\mathrm{N}=102)$

\begin{tabular}{ccc}
\hline General Characteristics & Sub Characteristics & Percentage \\
\hline Sex & Male & 41.2 \\
Age & Female & 58.8 \\
& Less than 30 years & 20.6 \\
& $31-35$ years & 54.9 \\
Education & $36-40$ years & 76.7 \\
& More than 40 years & 7.8 \\
& Bachelor & 80.4 \\
Length of service & Masters & 9.8 \\
& PhD/Professional doctorate & 19.6 \\
& Less than 3 years & 49.0 \\
& $4-7$ years & 26.5 \\
Field of study & $8-11$ years & 2.9 \\
& Social sciences and humanities & 2.0 \\
& Sciences and technology & 58.8
\end{tabular}

Table 2. Results of Validity and Reliability Analyses

\begin{tabular}{cccccccc}
\hline Measures & Item & $\begin{array}{c}\text { Factor } \\
\text { Loadings }\end{array}$ & KMO & $\begin{array}{c}\text { Bartlett's Test } \\
\text { of Sphericity }\end{array}$ & Eigenvalue & $\begin{array}{c}\text { Variance } \\
\text { Explained }\end{array}$ & $\begin{array}{c}\text { Cronbach } \\
\text { Alpha }\end{array}$ \\
\hline Responsiveness & 4 & $0.62-0.89$ & 0.78 & $180.25, \mathrm{p}=.0005$ & 2.76 & 68.97 & 0.85 \\
Assurance & 3 & $0.60-0.90$ & 0.63 & $118.20, \mathrm{p}=.0005$ & 2.15 & 71.70 & 0.80 \\
Empathy & 3 & $0.47-0.60$ & 0.66 & $98.50, \mathrm{p}=.0005$ & 2.12 & 70.62 & 0.78 \\
Perceived Value & 3 & $0.62-0.89$ & 0.78 & $180.25, \mathrm{p}=.0005$ & 2.76 & 68.97 & 0.85 \\
$\begin{array}{c}\text { Customer } \\
\text { Satisfaction }\end{array}$ & 4 & $0.60-0.90$ & 0.63 & $118.20, \mathrm{p}=.0005$ & 2.15 & 71.70 & 0.80 \\
\hline
\end{tabular}

Table 3. Correlation between Variables and Descriptive Statistics

\begin{tabular}{cccccccc}
\hline Variable & Mean & Standard & \multicolumn{5}{c}{ Pearson Correlation } \\
\cline { 4 - 8 } & & Deviation & 1 & 2 & 3 & 4 & 5 \\
\hline 1. Responsiveness & 5.22 & 0.64 & $(1)$ & & & & \\
2. Assurance & 5.10 & 0.78 & $0.51^{* *}$ & $(1)$ & & & \\
3. Empathy & 5.01 & 0.83 & $0.55^{* *}$ & $0.64^{* *}$ & $(1)$ & & \\
4. Perceived Value & 5.25 & 0.79 & $0.47^{* *}$ & $0.35^{* *}$ & $0.56^{* *}$ & $(1)$ & \\
5. Customer & 5.43 & 0.59 & $0.59^{* *}$ & $0.54^{* *}$ & $0.53^{* *}$ & $0.50^{* *}$ & $(1)$ \\
Satisfaction & & & & & & & \\
\hline
\end{tabular}

Note: Correlation value is significant at ${ }^{*} \mathrm{p}<0.05 ;{ }^{* *} \mathrm{p}<0.01 ;{ }^{* *} \mathrm{p}<0.001$

Reliability estimation are shown diagonally (value 1 ) 
Table 4. Results for Hierarchical Regression Analysis with Perceived Value as the Moderating Variable and Customer Satisfaction as the Dependent Variable

\begin{tabular}{|c|c|c|c|}
\hline \multirow[t]{2}{*}{ Variables } & \multicolumn{3}{|c|}{ Customer Satisfaction } \\
\hline & Model 1 & Model 2 & Model 3 \\
\hline \multicolumn{4}{|l|}{ Controling Variable } \\
\hline Sex & 0.28 & 0.09 & 0.10 \\
\hline Age & 0.06 & -0.02 & 0.02 \\
\hline Education & 0.17 & 0.18 & 0.15 \\
\hline Length of service & -0.07 & -0.10 & -0.08 \\
\hline Faculty & 0.09 & 0.13 & 0.13 \\
\hline \multicolumn{4}{|l|}{$\underline{\text { Independent Variable }}$} \\
\hline Responsiveness & & 0.35 & 0.39 \\
\hline Assurance & & 0.25 & 1.45 \\
\hline Empathy & & 0.07 & -1.05 \\
\hline Perceive Value & & 0.18 & 0.57 \\
\hline$\underline{\text { Moderating Variable }}$ & & & -0.22 \\
\hline Reponsiveness $\mathrm{x}$ Perceive Value & & & -1.83 \\
\hline Assurance $\mathrm{x}$ Perceive Value & & & $1.72 *$ \\
\hline \multicolumn{4}{|l|}{ Empathy $\mathrm{x}$ Perceive Value } \\
\hline $\mathrm{R}^{2}$ & 0.10 & 0.53 & 0.56 \\
\hline $\mathrm{R}^{2}$ Adjusted & 0.05 & 0.48 & 0.49 \\
\hline $\mathrm{F}$ & 2.14 & $11.46^{* * *}$ & $9.34 * * *$ \\
\hline $\mathrm{R}^{2}$ Change & 0.10 & 0.43 & 0.03 \\
\hline $\mathrm{F} \Delta \mathrm{R}^{2}$ & 2.14 & $20.90 * * *$ & 1.93 \\
\hline
\end{tabular}

Note: Correlation value significant at ${ }^{*} \mathrm{p}<0.05,{ }^{* *<0.01,},{ }^{* * *} \mathrm{p}<0.001$ 